\title{
TO ASSESS THE KNOWLEDGE AND ATTITUDE OF ADOLESCENTS REGARDING THE ADVERSE EFFECTS OF SOCIAL NETWORKING AT S.G.R.R PUBLIC SCHOOL, PATEL NAGAR, DEHRADUN, UTTRAKHAND
}

\author{
POOJA CHAND ${ }^{1}$, JASLINE $M^{2}$, RAJESH B ${ }^{2}$ \\ ${ }^{1}$ Department of Nursing, ERA College of Nursing, Lucknow, Uttar Pradesh, India, ${ }^{2}$ Department of Nursing, Teerthanker Mahaveer College of \\ Nursing, Moradabad, Uttar Pradesh, India
}

Received: 03 March 2021, Revised and Accepted: 07 August 2021

\section{ABSTRACT}

Objectives: The aim of the study is to assess the knowledge and attitude of adolescents regarding the adverse effects of social networking.

Methods: A descriptive research design was adopted for the study, conducted at S.G.R.R Public School, Patel Nagar, Dehradun, Uttarakhand. Nonprobability purposive sampling technique is used for data collection, knowledge questionnaire and Likert scale is used for the study.

Results: The study results reveals that $2.5 \%$ of participants were having adequate knowledge. Moderate knowledge score was $92.5 \%$. Inadequate knowledge score was $5 \%$. Likert scale shows that $42 \%$ of adolescents are agree, $35.2 \%$ are strongly disagree, $28.8 \%$ are strongly agree, $28.4 \%$ are neutral, and $26.4 \%$ are disagree.

Conclusion: The conclusion of the study reveals that the moderate knowledge score was $92.5 \%$ and in Likert scale highest percentage, $42 \%$ of adolescents are agree, so the attitude regarding adverse effects of social networking is positive.

Keywords: Adverse effects of social networking, Likert scale, Knowledge.

(C) 2021 The Authors. Published by Innovare Academic Sciences Pvt Ltd. This is an open access article under the CC BY license (http://creativecommons, org/licenses/by/4.0/) DOI: http://dx.doi.org/10.22159/ijms.2021v9i5.41281. Journal homepage: https://innovareacademics.in/journals/index.php/ijms

\section{INTRODUCTION}

"Technology is so much fun but we can drown in our technology. The fog of information can drive our knowledge."

\section{DANIEL J.BOORSTIN \{New York Times, July 8, 1983\}}

The $21^{\text {st }}$ century has opened new avenues and horizons of progress and development through advancement in technology, lifestyle, and social relationship all around the world. The internet is a global network connecting millions of computers. More than 100 countries are linked into exchanges of data, news, and opinions. According to Internet World Stats, as of December 31, 2011, there was an estimated $2,267,233,742$ internet users worldwide [1]. This represents $32.7 \%$ of the world's population. Reading is one of the oldest habits of human civilization. It has been the passion of the greatest personalities of all times [2]. One of the first documentary sources for reading was manuscript. The revolution in the mass media, telecommunication, and social networking with the emerging advancement in science and technology has made the drastic change in access and browse of the online information from the whole web using terminal at home [3].

The internet is a global linking of computers that allows information transfer. Due to the development and spread of cheaper and more user-friendly computer technology and software (e.g., portable computers, Microsoft Word, etc.), the use of the internet has increased dramatically [4].

Teenagers are among the most prolific users of social networking sites (SNSs) emerging studies find that youth spend a considerable portion of their daily life interacting through social media. SNSs have gained much popularity in the recent years, because of the opportunities they give people to connect to each other in an easy and timely manner, and to exchange and share various kinds of information [5]. However, these sites are architected based on a centralized paradigm, which limits the mobility of their users, and ultimately, their chances for establishing new relationships and benefiting from diverse networking services [6]. In this paper, we argue for a decentralized paradigm for social networking, in which users retain control of their profiles, and SNSs focus on the delivery of innovative and competitive services. Our position is that only in this environment will both the SNSs and their users be able to develop to their full potential [7]

According to the report, the number of mobile internet users increased to 87.1 million by December 2012 from 78.7 million users in October 2012, who accessed the internet through dongles and tablets PCs [8]. This is expected to grow further to 92.9 million (by March 2013), 130.6 million (by March 2014) [9], and 164.8 million by March 2015 [14]. There is an increasing concern from educators, psychologists, and parents about the negative effects of using the internet on the physical (e.g., information fatigue syndrome), cognitive (e.g. inability to discriminate between the real and cyber world) [10], and social development (e.g., identity confusion) of children (Cordes and Miller, 2000), among which, detriment to social development (hurting children's skills and patience to conduct necessary social relations in the real world) is a paramount problem (Affonso, 1999) [12]. One of the most serious concerns regarding children's social development involves the proliferation and easy accessibility of negative content on the internet, such as pornography, violence, hate speech, gambling, sexual solicitation, and so forth (Internet Advisory Board, 2001; ParentLink, 2004) [11]. It is easy to see how these types of negative content harm children and destroy their development [13].

Statement of the problem

"A STUDY TO ASSESS THE KNOWLEDGE AND ATTITUDE OF ADOLESCENTS REGARDING THE ADVERSE EFFECTS OF SOCIAL NETWORKING AT S.G.R.R PUBLIC SCHOOL, PATEL NAGAR, DEHRADUN, UTTRAKHAND." 
Table 1: Likert scale for attitude

\begin{tabular}{lccccc}
\hline Scale & $\begin{array}{c}\text { Strongly } \\
\text { disagree }\end{array}$ & Disagree & Neutral & Agree & $\begin{array}{c}\text { Strongly } \\
\text { agree }\end{array}$ \\
\hline Percentage & 35.2 & 26.4 & 28.4 & 42 & 28.8 \\
\hline
\end{tabular}

\section{METHOS}

The nature of study was descriptive. The study was conducted in SGRR Public School, Patel Nagar, Dehradun. The conceptual framework selected for this study was based on HEALTH BELIEF MODEL proposed by ROSEN STOCK'S AND BECKERS in the year 1974. Descriptive research design was used. Data were collected using non-probability purposive sampling technique. The tool used for the study is knowledge questionnaires and Likert scale. The data collected were analyzed and interpreted using descriptive and inferential statistics.

\section{Ethical consideration}

To conduct research study in SGRR Public School, written permission was obtained from Principal of SGRR Public School, before data collection. They gave the permission to conduct the study in SGRR Public School. Confidentiality was assured to all the subjects to get, formal their cooperation. An informed consent was taken from the subjects before collecting data.

\section{RESULTS AND DISCUSSION}

The study results revealed that the highest percentage of students $75 \%$ was in 16-17 years. In gender wise, female is $65 \%$ and male is $35 \%$. In religion wise, $80 \%$ of students were Hindu, $17.5 \%$ of students were Muslim, and $2.5 \%$ of students were Sikh. About $97.5 \%$ of students belongs to urban, $2.5 \%$ belongs to rural. About $57.5 \%$ of students belong to joint family, $37.5 \%$ of students were nuclear family, and $5 \%$ of students were extended family. About $47.5 \%$ of student fathers are private employee, $22.5 \%$ of student fathers are self-employee, $20 \%$ of student fathers are self-employee, $20 \%$ of student fathers are govt. employee, $7.5 \%$ of fathers are retired, and $2.5 \%$ of fathers are unemployed.

In parent's education wise, $30 \%$ of parents had graduation or above, than $22.5 \%$ of parents were higher and secondary education, $15 \%$ of parents were primary education, and $10 \%$ of parents were no formal education. And in source of information shows that highest percentage $45 \%$ of students were having information from friends, $35 \%$ having information from mass media, $12.5 \%$ having information from family members and $7.5 \%$ of students having information from teachers regarding Social networking. Percentage wise distribution of students reveals that $100 \%$ of students are using social networking. Moreover, $55 \%$ of students start using social networking in 16-17 years of age, $30 \%$ students were in $14-15$ years of age, $10 \%$ of students are in $17-$ 18 years of age, and $5 \%$ of students are in $12-13$ years of age.

The study results reveals that $2.5 \%$ of participants were having adequate knowledge. Moderate knowledge score was $92.5 \%$. Inadequate knowledge score was $5 \%$. Likert scale shows that $42 \%$ of adolescents are agree, $35.2 \%$ are strongly disagree, $28.8 \%$ are strongly agree, $28.4 \%$ are neutral, and $26.4 \%$ are disagree.

Hence, the moderate knowledge score was $92.5 \%$ and in Likert scale highest percentage $42 \%$ of adolescents are agree so the attitude regarding adverse effects of social networking is positive.

The study proved that there was not significant association between knowledge score and selected demographic variables (age, gender, religion, area of living, type of family, father occupation, education of parents, source of information, using social networking, and what age face book account begin) at 0.05 level of significance.

\section{CONCLUSION}

The study results reveals that $2.5 \%$ of participants were having adequate knowledge. Moderate knowledge score was $92.5 \%$. Inadequate knowledge score was $5 \%$. Likert scale shows that $42 \%$ of adolescents are agree, $35.2 \%$ are strongly disagree, $28.8 \%$ are strongly agree, $28.4 \%$ are neutral, and $26.4 \%$ are disagree. Hence, the moderate knowledge score was $92.5 \%$ and in Likert scale highest percentage $42 \%$ of adolescents are agree so the attitude regarding adverse effects of social networking is positive.

\section{ACKNOWLEDGMENTS}

The authors wish to acknowledge to all the participants for their gracious cooperation in this project.

\section{AUTHORS' CONTRIBUTIONS}

All the authors have contributed equally in the research.

\section{CONFLICTS OF INTEREST}

All authors declared that no conflicts of interest exist.

\section{FUNDING}

This is a non-funded project.

\section{REFERENCES}

1. Neerja KP. Textbook of Sociology for Nursing Students. Jaypee Publications; 2010. p. 144-8.

2. Vidya B, Sachdeva RD. An Introduction to Sociology. Allahabad: Kitab Mahal; 2020. p. 273-80.

3. Anthony G. Book of Sociology. $5^{\text {th }}$ ed. Fort Worth, TX: Harcourt; 2000. p. $122-35$.

4. Neeraj P. Sociology for Health Professionals. $2^{\text {nd }}$ ed. Walters Kluwer; 152-5.

5. Victor S, Social Media and its Terrifying Negative effects on people with Depression and Anxiety. Kindle Store Publication; 2017. p. 89-95.

6. Sheikh UJ. An Investigation into the Negative effects of Social Media: Information Technology and Management. Maude Avenue, Sunnyvale: GeoSpatial Technology, LAP Lamber Academic Publishing; 256-65.

7. Ahn J. The effect of social network sites on adolescents' academic and social development: Current theories and controversies. J Am Soc Inf Sci Technol 2011;62:1435-45.

8. Ahn J. Digital divides and social network sites: Which students participate in social media? J Educ Comput Res 2011;45:147-63.

9. Danah B. Friends, Friendsters, and MySpace Top 8: Writing Community Into Being on Social Network Sites. First Monday 2006;11:255-87.

10. Kuppuswamy S, Narayan PB. The impact of social networking websites on the education of youth. Int J Virtual Commun Soc Netw 2011;2:67-79.

11. Jain MR, Anand N, Gupta P. Impact of social networking sites in the changing mindset of youth on social issues a study of Delhi-NCR youth. J Arts Sci Commerce 2012;3:36-43.

12. Adverse Effect of Using Internet. Available from: http://www.iml.jou. ufl.edu/projects/STUDENTS/Liu/kadv.htm.

13. Basic Internet Definitions. Available from: http://www.pierobon.org/ iis/internet.htm. [Last accessed on 2018 Mar 02]

14. Children's Exposure to Negative Internet Content: Effects of Family Context, By Cheon, Hongsik John, Publication: Journal of Broadcasting and Electronic Media; 2005. Available from: http://www.researchgate. net; http://www.highbeam.com/doc/1G1-142207316.html. [Last accessed on 2005 Dec 01]. 